\title{
Prevalence and factors associated with sepsis and septic shock in oncological patients in intensive therapy
}

\author{
Prevalência e fatores associados à sepse e choque séptico em pacientes oncológicos em terapia intensiva
}

Prevalencia y factores relacionados a la sepsis y choque séptico en pacientes oncológicos en cuidados intensivos

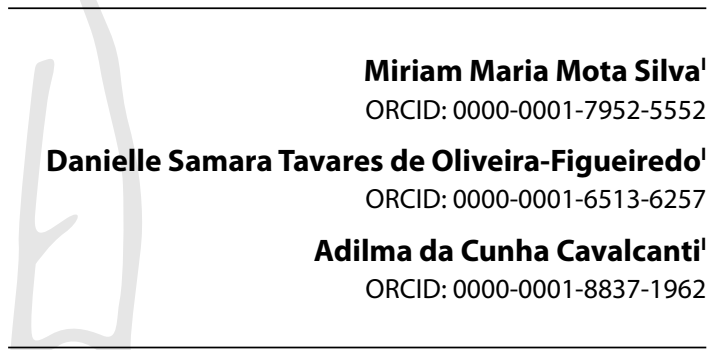

'Universidade Federal de Campina Grande. Campina Grande, Paraíba, Brazil.

How to cite this article:

Silva MMM, Figueiredo DSTO, Cavalcanti AC. Prevalence and factors associated with sepsis and septic shock in oncological patients in intensive therapy.

Rev Bras Enferm. 2022;75(1):e20201338. https://doi.org/10.1590/0034-7167-2020-1338

Corresponding author:

Miriam Maria Mota Silva E-mail:miriammary2011@gmail.com

EDITOR IN CHIEF: Antonio José de Almeida Filho ASSOCIATE EDITOR: Álvaro Sousa

Submission: $01-23-2021$

Approval: 04-25-202

\section{ABSTRACT}

Objectives: to analyze factors associated with sepsis and septic shock in cancer patients in the Intensive Care Unit. Methods: cross-sectional, retrospective study with a quantitative approach, with a sample of 239 patients in an oncology hospital. Secondary data from medical records were used. The outcome variable was "presence of sepsis and/or septic shock"; and exposures: sex, length of stay, origin, use of invasive procedures and primary tumor site. Descriptive, bivariate analyzes and multiple logistic regression models were performed. Results: the prevalence of sepsis was $95 \% \mathrm{Cl}: 14.7-24.7$ and septic shock of $95 \% \mathrm{Cl}: 37.7-50.3$. In the multiple analysis, sepsis and/or septic shock were associated with hospital stay longer than seven days, being from the Emergency Department, presence of invasive procedures and hematological site. Conclusions: sepsis and/or septic shock in cancer patients were associated with clinical characteristics and health care factors.

Descriptors: Sepsis; Septic Shock; Patients; Oncology; Intensive Care Units.

\section{RESUMO}

Objetivos: analisar fatores associados à sepse e choque séptico em pacientes oncológicos em Unidade de Terapia Intensiva. Métodos: estudo transversal, retrospectivo, de abordagem quantitativa, com amostra de 239 pacientes em um hospital oncológico. Utilizaram-se dados secundários dos prontuários. A variável-desfecho foi "presença de sepse e/ou choque séptico"; e as exposições: sexo, tempo de internação, procedência, uso de procedimentos invasivos e sítio do tumor primário. Realizaram-se análises descritivas, bivariadas e modelos de regressão logística múltipla. Resultados: a prevalência de sepse foi IC95\%: 14,7-24,7 e choque séptico de IC95\%:37,7-50,3. Na análise múltipla, a sepse e/ou choque séptico associaram-se ao tempo de internação maior que sete dias ( $\mathrm{OR}=2,29 \mathrm{IC} 95 \%: 1,25-4,2)$, ser procedente da Urgência $(\mathrm{OR}=3,21$; IC 95\%: 1,57-6,57), presença de procedimentos invasivos (OR=11,4 IC95\%:1,81-72,0) e sítio hematológico (OR=2,22 IC5\%: 1,07-4,61). Conclusões: a sepse e/ou choque séptico em pacientes oncológicos se associaram às características clínicas e fatores da assistência à saúde. Descritores: Sepse; Choque Séptico; Pacientes; Oncologia; Unidades de Terapia Intensiva.

\section{RESUMEN}

Objetivos: analizar factores relacionados a la sepsis y choque séptico en pacientes oncológicos en Unidad de Cuidados Intensivos. Métodos: estudio transversal, retrospectivo, de abordaje cuantitativo, con muestra de 239 pacientes en un hospital oncológico. Utilizados datos secundarios de los prontuarios. La variable-desfecho fue "presencia de sepsis y/o choque séptico"; y las exposiciones: sexo, tiempo de internación, procedencia, uso de procedimientos invasivos y lugar del tumor primario. Realizados análisis descriptivos, bivariadas y modelos de regresión logística múltiple. Resultados: prevalencia de sepsis fue IC95\%: 14,7-24,7 y choque séptico de IC95\%: 37,7-50,3. En el análisis múltiple, la sepsis y/o choque séptico se relacionaron al tiempo de internación mayor que siete días (OR=2,29 IC95\%:1,25-4,2), ser procedente de Urgencia (OR=3,21; IC 95\%: 1,57-6,57), presencia de procedimientos invasivos (OR=11,4 IC95\%:1,81-72,0) y lugar hematológico (OR=2,22 IC5\%: 1,07-4,61). Conclusiones: la sepsis y/o choque séptico en pacientes oncológicos se relacionaron a características clínicas y factores de asistencia de salud. Descriptores: Sepsis; Choque Séptico; Pacientes; Oncología; Unidades de Cuidados Intensivos. 


\section{INTRODUCTION}

Cancer is a potential public health problem and represents the second cause of morbidity and mortality among chronic non-communicable diseases, behind only cardiovascular diseases $^{(1)}$. In Brazil, in 2018, it was estimated that the cancer incidence rate was 265.3 per 100 thousand inhabitants ${ }^{(2)}$. For the 2020-2022 biennium, estimates point to differences in incidence rates between the sexes, being higher among men, 215.8 per 100 thousand inhabitants, than among women, 145 per 100 thousand inhabitants ${ }^{(3)}$. In the same period, in Brazil, it is estimated that approximately 625 thousand new cases may occur ${ }^{(3)}$.

The Intensive Care Unit (ICU) is a sector that provides therapeutic support to cancer patients during higher risk and severity in the treatment or in cases of complications of the disease ${ }^{(4)}$. Sepsis is a frequent complication in these patients and has a four-fold higher incidence in this group, being the main cause of death unrelated to cancer $^{(5)}$.

The third international consensus (Sepsis-3) ${ }^{(6)}$ defines sepsis as a life-threatening organ dysfunction, caused by an unregulated host response to infection ${ }^{(6)}$. In clinical terms, sepsis is present when there is a suspected or documented infection associated with its acute increase, greater than or equal to two points on the Sequential [Sepsis-related] Organ Failure Assessment (SOFA) score, which may indicate an organ dysfunction ${ }^{(6)}$.

In addition, when professionals suspect an infectious condition that can increase the risk of prolonged ICU stay or death, quick-SOFA (qSOFA) can be applied quickly at the bedside - a screening score that assesses changes in mental status, systolic blood pressure less than or equal to $100 \mathrm{mmHg}$ and respiratory rate greater than or equal to $22 \mathrm{irpm}^{(6)}$. The presence of at least two of these criteria points to a higher risk of unfavorable outcomes and may indicate a possible infection in a patient with suspected infection ${ }^{(6)}$.

Septic shock is a subset of sepsis characterized by marked circulatory, cellular and metabolic abnormalities that can potentially increase the risk of mortality compared to sepsis alone ${ }^{(6)}$. In clinical terms, septic shock is present when the patient with sepsis needs to use vasopressor drugs to maintain mean arterial pressure (MAP) at $65 \mathrm{mmHg}$ or more and the serum lactate level is greater than $2 \mathrm{mmol} / \mathrm{L}$ in the absence of hypovolemia ${ }^{(6)}$.

Cancer patients are about ten times more likely to develop sepsis when compared to individuals without neoplasms, and for hematological malignancies, the risk is between seven and eight times higher when compared to solid tumors ${ }^{(7)}$. In addition, sepsis is one of the most costly pathologies to be treated in the hospital environment ${ }^{(8)}$. In the adult population in general ICUs, the incidence of sepsis can reach $54.7 \%$; and septic shock, $15.8 \%{ }^{(9)}$.

Previous international and national studies have associated sepsis and septic shock with the length of hospital stay ${ }^{(8)}$, limitations on the availability of basic resources for the treatment of sepsis, and the lack of knowledge of health professionals to recognize and initiate early treatment, as well as low adherence to preventive infection measures ${ }^{(10)}$.

On the other hand, it is observed that the current scientific evidence, such as that of the Surviving Sepsis Campaign, does not include clinical guidelines that consider the factors associated with sepsis and septic shock in this specific population of cancer patients ${ }^{(11)}$. In addition, studies in this area have focused on discussing clinical and therapeutic approaches; most of them are descriptive, limited to describing the sociodemographic and clinical profile; or even do not study sepsis and septic shock as an outcome ${ }^{(12-13)}$. Other investigations were carried out in sectors such as Urgency and Emergency ${ }^{(14)}$, Wards and Hematological Outpatients ${ }^{(8)}$, thus presenting gaps regarding the factors associated with the occurrence of sepsis and septic shock in patients hospitalized in oncology ICUs.

Thus, knowledge about the factors associated with sepsis and septic shock in adult patients in an oncology ICU can facilitate both the adoption of preventive measures and their early recognition. Therefore, it is possible to guide the conduct of nursing professionals and a multidisciplinary team to reduce morbidity and mortality in cancer patients.

\section{OBJECTIVES}

To analyze the factors associated with sepsis and septic shock in cancer patients in the Intensive Care Unit.

\section{METHODS}

\section{Ethical aspects}

This research complied with the ethical precepts of Resolution 466/2012 and Resolution 564/2017 - the latter reformulates the Code of Ethics for Nursing Professionals. Data collection was only carried out after approval by the Research and Ethics Committee (REC) and obtaining the Certificate of Presentation for Ethical Appreciation (CAAE) ${ }^{(15-16)}$.

\section{Study design, period, and location}

This is a cross-sectional, retrospective study with a quantitative approach. It was carried out with secondary data from medical records of adult cancer patients who were hospitalized, from January 1 to December 31, 2018, in an oncology ICU for adults, which had ten beds and was part of a medium-sized philanthropic hospital, a reference in cancer treatment, in the city of Recife, state of Pernambuco (PE).

This research was guided by the Strengthening the Reporting of Observational Studies in Epidemiology (STROBE) tool.

\section{Population and sample: inclusion and exclusion criteria}

The population consisted of 293 patients who were hospitalized at the study site. This universe corresponds to the total number of hospitalizations in 2018 , so, for the establishment of the sample, a census survey of that year was used. On the other hand, the medical records of individuals who had all the variables of interest properly filled in were included; and those whose data were incomplete or unavailable for collection at the statistical medical filing service were excluded.

\section{Study protocol}

The data collection instrument was built by the researchers based on the current relevant literature on sepsis in cancer 
patients ${ }^{(10,12,14)}$ and was subjected to a pilot test with ten patients to verify their suitability, prior to data collection.

The data collection period was from May 7 to November 4, 2019, at the hospital's statistical medical filing service. The independent variables of interest were: gender $(0$ - male and 1 - female); hospitalization time ( 0 - one to seven days and 1 above seven days); patient's origin ( 0 - Surgical, 1 - Medical Clinic, 2 - Onco-clinic, 3 - Hematology, 4 - Urgency, 5 - Surgical ICU, 6 - Pediatrics); primary tumor site (0 - solid, 1 - hematological, 2 - indeterminate); use of invasive procedures ( 0 - no procedures; 1 - one to three procedures, 2 - four or more procedures). The dependent variable was the occurrence of sepsis or septic shock (0 - No and 1 - Yes).

For the construction of the outcome "presence of sepsis or septic shock", the sum of all patients who were diagnosed with sepsis or septic shock was initially performed. This variable had the following categories: 0 - did not present a diagnosis; 1 presented sepsis; 2 - presented septic shock. Subsequently, the outcome was dichotomized into: 0 - did not present a diagnosis; and 1 - had a diagnosis of sepsis or septic shock.

Sepsis and/or septic shock were considered present when there was a medical diagnosis in the medical record during any time of hospitalization in the ICU. The age group of the patients was taken as a confounding variable.

\section{Analysis of results and statistics}

The analyzes were carried out through the construction of a database in the Excel for Windows software; then, the data were analyzed using the Stata software (version 13.1). Initially, a descriptive and exploratory step of the variables was carried out by calculating simple and percentage frequencies. Bivariate analyzes were performed to verify the possible associations of the independent variables with the outcome; for that, the chi square test was used. Variables with $p$ less than 0.20 in the bivariate analysis were considered for the multivariate analysis.

For the multiple logistic regression, the forward criterion was used, whereby all the variables selected in the bivariate stage were inserted one by one in the model. For the introduction of the variables, it started with the outcome; then, the exposures of interest and the confounding variable were addressed. The variables that remained significant, with p less than 0.05 , according to the Wald test, made up the final (adjusted) model. The magnitude of the association was measured using the unadjusted odds ratio (OR) and adjusted with respective $95 \%$ confidence intervals. A $5 \%$ significance level was adopted.

\section{RESULTS}

The final sample consisted of 239 users, with a predominance of females (143; 59.8\%), with ages ranging from 19 to 91 years, median of 61 years (interquartile range $=50-70$ ) and predominance of the elderly (126; 52, 7\%) (Table 1). Most patients were from the Emergency Department $(102 ; 42.7 \%)$ and 71 (29.7\%) had medical diagnoses of two or more comorbidities.

The prevalence of sepsis was $19.2 \%$ (95\% Cl: 14.7-24.7); and septic shock, $43.9 \%$ (95\% Cl: 37.7-50.3).
Table 1 - Distribution of sociodemographic and clinical characteristics of cancer patients, Recife, Pernambuco, Brazil, 2019

\begin{tabular}{lccc}
\hline Sociodemographic characteristics & $\mathbf{n}$ & $\%$ & $\mathbf{C l} \mathbf{9 5 \%}$ \\
\hline Sex & & & \\
$\quad$ Female & 143 & 59.8 & $53.4-65.9$ \\
$\quad$ Male & 96 & 40.2 & $34.0-46.5$ \\
Age group & & & \\
$\quad 19$ to 29 & 10 & 4.2 & $2.2-7.6$ \\
30 to 39 & 21 & 8.8 & $1.8-13.1$ \\
$\quad 40$ to 49 & 25 & 10.5 & $7.1-15.0$ \\
50 to 59 & 57 & 23.9 & $18.8-29.7$ \\
$\quad$ Equal or > 60 & 126 & 52.7 & $46.3-59.0$ \\
Origin & & & \\
$\quad$ Surgical Clinic & 65 & 27.2 & $22.1-33.6$ \\
$\quad$ Oncoclinic & 33 & 13.8 & $10.0-19.0$ \\
$\quad$ Urgency & 102 & 42.7 & $37.0-49.6$ \\
$\quad$ Others & 39 & 16.3 & $11.1-20.4$ \\
Sepsis & & & \\
$\quad$ No & 196 & 82 & $75.2-85.2$ \\
$\quad$ Yes & 43 & 19.2 & $14.7-24.7$ \\
Septic shock & & & \\
$\quad$ No & 134 & 56.1 & $49.6-62.2$ \\
$\quad$ Yes & 105 & 43.9 & $37.7-50.3$ \\
\hline Cl-95\% confidence interval. & & &
\end{tabular}

In the bivariate analysis, they were associated with the occurrence of sepsis or septic shock: length of stay, origin of the patient (prior to admission to the oncology ICU) and the presence of invasive procedures. The following characteristics were suitable for the multiple logistic regression model: sex, length of stay, origin, primary tumor site and presence of invasive procedures $(p<0.20)$ (Table 2). Table 3 presents the unadjusted and adjusted odds ratios for the occurrence of sepsis/septic shock, according to sociodemographic and clinical characteristics.

Table 2 - Association of sociodemographic and clinical characteristics with sepsis/septic shock in cancer patients $(N=239)$, Recife, Pernambuco, Brazil, 2019

\begin{tabular}{|c|c|c|c|}
\hline \multirow{2}{*}{ Characteristics } & \multirow{2}{*}{ n total (\%) } & \multicolumn{2}{|c|}{ Sepsis or septic shock } \\
\hline & & n (\%) & $p$ \\
\hline \multicolumn{4}{|l|}{ Sex } \\
\hline Female & $143(59.8)$ & $82(57.3)$ & \multirow[t]{2}{*}{0.075} \\
\hline Male & $96(40.1)$ & $66(68.7)$ & \\
\hline \multicolumn{4}{|l|}{ Length of Hospitalization } \\
\hline 1 to 7 days & $135(56.5)$ & $72(53.3)$ & \multirow[t]{2}{*}{0.002} \\
\hline More than 7 days & $104(43.5)$ & $76(73.1)$ & \\
\hline \multicolumn{4}{|l|}{ Origin } \\
\hline Surgical Clinic & $65(27.5)$ & $30(46.1)$ & \multirow{4}{*}{0.002} \\
\hline Oncoclinic & $33(14.0)$ & $17(51.5)$ & \\
\hline Urgency & $102(43.2)$ & $76(74.5)$ & \\
\hline Others & $39(16.3)$ & $22(61.1)$ & \\
\hline \multicolumn{4}{|l|}{ Primary tumor site } \\
\hline Solid & $169(70.7)$ & $97(57.4)$ & \multirow{3}{*}{0.079} \\
\hline Hematological & $67(28.0)$ & $49(73.1)$ & \\
\hline Indeterminate & $3(1.26)$ & $2(66.7)$ & \\
\hline \multicolumn{4}{|l|}{ Invasive procedure } \\
\hline No procedure & $11(3.0)$ & $2(28.6)$ & \multirow{3}{*}{0.005} \\
\hline 1 to 3 procedures & $121(51.5)$ & $68(56.2)$ & \\
\hline 4 or more procedures & $107(45.5)$ & 78 (72.9) & \\
\hline
\end{tabular}

In the multiple model, the occurrence of sepsis or septic shock was associated with a hospital stay longer than seven days (OR = 2.29 95\% Cl: 1.25-4.2), being from the Emergency Department (OR 
$=3,21 ; 95 \% \mathrm{Cl}: 1.57-6.57)$, the hematological primary tumor site (OR $=2.22 \mathrm{Cl}$ \% : 1.07-4.61) and the presence of four or more invasive procedures (OR $=11.495 \% \mathrm{Cl}: 1.81-72.0)$, regardless of age group. Patients hospitalized for more than a week are twice as likely to develop sepsis/septic shock when compared to those hospitalized for less than/up to seven days (adjusted $\mathrm{OR}=2.29 ; 95 \% \mathrm{Cl}: 1.25-4.2$ ).

It was also observed that patients from the Emergency Department, when compared to those from the Surgical Clinic, may have a greater chance of developing sepsis and or septic shock during hospitalization in an oncology ICU. Another important result of this study was that the presence of four or more invasive procedures performed on the patient was associated with a greater chance of sepsis/septic shock (Table 3).

Table 3 - Odds ratio (OR) not adjusted and adjusted for the occurrence of sepsis/septic shock in cancer patients according to sociodemographic and clinical characteristics $(N=239)$, Recife, Pernambuco, Brazil, 2019

\begin{tabular}{|c|c|c|c|c|}
\hline \multirow[b]{2}{*}{ Characteristics } & \multicolumn{4}{|c|}{ Sepsis or septic shock } \\
\hline & $\begin{array}{c}\text { OR not } \\
\text { adjusted } \\
(95 \% \mathrm{CI})^{\mathrm{a}}\end{array}$ & $p$ & $\begin{array}{c}\text { OR not } \\
\text { adjusted } \\
(95 \% \mathrm{Cl})^{\mathrm{b}}\end{array}$ & $p$ \\
\hline $\begin{array}{l}\text { Sex } \\
\text { Female } \\
\text { Male }\end{array}$ & $\begin{array}{c}\text { Ref. } \\
1.63(0.94-2.82)\end{array}$ & 0.076 & - & - \\
\hline $\begin{array}{l}\text { Length of hospital stay } \\
1 \text { to } 7 \text { days } \\
\text { More than } 7 \text { days }\end{array}$ & $\begin{array}{c}\text { Ref. } \\
2.37(1.37-4.11)\end{array}$ & 0.002 & $\begin{array}{c}\text { Ref. } \\
2.29(1.25-4.2)\end{array}$ & 0.007 \\
\hline $\begin{array}{l}\text { Origin } \\
\text { Surgical Clinic } \\
\text { Oncoclinic } \\
\text { Urgency } \\
\text { Others }\end{array}$ & $\begin{array}{c}\text { Ref. } \\
1.23(0.53-2.86) \\
3.41(1.76-6.6) \\
1.83(0.8-4.1)\end{array}$ & $\begin{array}{c}0.616 \\
<0.001 \\
0.152\end{array}$ & $\begin{array}{c}\text { Ref. } \\
- \\
3.21(1.57-6.57) \\
-\end{array}$ & 0.001 \\
\hline $\begin{array}{l}\text { Primary tumor site } \\
\text { Solid } \\
\text { Hematological } \\
\text { Indeterminate }\end{array}$ & $\begin{array}{c}\text { Ref. } \\
2.02(1.08-3.75) \\
1.48(0.13-16.6)\end{array}$ & $\begin{array}{l}0.026 \\
0.749\end{array}$ & $\begin{array}{c}\text { Ref. } \\
2.22(1.07-4.61) \\
-\end{array}$ & 0.031 \\
\hline $\begin{array}{l}\text { Invasive procedure } \\
\text { No procedure } \\
1 \text { to } 3 \text { procedures } \\
4 \text { or more procedures }\end{array}$ & $\begin{array}{c}\text { Ref. } \\
3.2(0.59-17.2) \\
6.7(1.23-36.5)\end{array}$ & $\begin{array}{l}0.174 \\
0.027\end{array}$ & $\begin{array}{c}\text { Ref. } \\
- \\
11.4(1.81-72.0)\end{array}$ & 0.010 \\
\hline
\end{tabular}

neutrophil chemotaxis, phagocytosis problems and reduced bactericidal capacity, which generates impaired immune responses to the infectious agent ${ }^{(22-24)}$. Added to this, the frequent use of blood transfusion, which can increase the risk of infection ${ }^{(22)}$.

In this research, some factors associated with the occurrence of sepsis or septic shock in cancer patients hospitalized in the ICU were related to the characteristics of health care, namely: being from the Emergency Department, the length of stay in the ICU greater than seven days and the presence of four or more invasive procedures. Cancer patients are exposed to several of these procedures, such as surgeries, long-term venous catheters, bladder and enteral catheters, and this can contribute to infections being installed, which can, in turn, trigger a case of sepsis or septic shock ${ }^{(25-26)}$.

Corroborating this finding, previous studies have also found similar results, in which sepsis was associated with the presence of invasive procedures and healthcare-related infections (HAIs) ${ }^{(18-27)}$. In this study, patients from the Emergency Department were more likely to develop sepsis or septic shock when compared to those from the Surgical Clinic, probably due to the use of urgent invasive procedures, which may increase the risk of infection due to the lack of rigor in aseptic technique - for example, delayed bladder catheterization (DBC), invasive mechanical ventilation (IMV), central venous catheterization (CVC) and other procedures, which are the main sites of $\mathrm{HAIs}^{(17)}$.

These results may show that some characteristics of health care have the potential to increase the chances of this outcome during hospitalization in oncology ICUs. HAls are adverse events acquired in the provision of health services, therefore they generate risks to patient safety that impact mortality rates, duration and costs in hospitalization ${ }^{(25)}$.

Therefore, adherence to evidence-based practices by health professionals is essential for the prevention of HAls and, consequently, of sepsis and septic shock in these intensive care environments ${ }^{(25)}$. Thus, it is important for the health team to adopt CVC insertion and maintenance bundles in their practice, defined

\section{DISCUSSION}

This study used secondary data from 239 patients who were admitted to the oncology ICU. Almost half of the patients in this study had septic shock, 43.9\% (95\% Cl: 37.7-50.3); almost a fifth had a picture of sepsis, $19.2 \%$ ( $95 \% \mathrm{Cl}: 14.7-24.7)$. This high prevalence is also evidenced in general ICUs, where the occurrence of sepsis can reach $39.1 \%$; and septic shock, $47 \%{ }^{(17)}$.

Sepsis is the main cause of admission to general ICUs in cancer patients, and neoplasms are the most common comorbidities in septic patients ${ }^{(18)}$. Thus, this group has a ten times greater risk of developing sepsis when compared to the general population; in addition, it has high rates of mortality from sepsis or septic shock ${ }^{(18-19)}$.

The high prevalence of sepsis and septic shock in cancer patients may be due to the greater susceptibility secondary to immunosuppressive treatments, as well as to the underlying pathology itself - as described, patients with oncological disease have a higher risk of sepsis and septic shock ${ }^{(20-21)}$ due to quantitative defects in as a set of three to five evidence-based measures that, when applied systematically and correctly, improve health care results ${ }^{(24)}$. As CVC insertion measures, the following stand out: the proper hand hygiene; use of alcoholic chlorhexidine gluconate $0.5 \%$ to $2 \%$ for skin preparation and friction; preference for puncture in the subclavian vein; and use of maximum barrier protection. As CVC maintenance measures, daily assessment of the insertion site, verification and dressing change is recommended - knowing that, for those made up of sterile gauze, the change must occur every 48 hours; and for those with transparent film, every seven days or earlier, if it is dirty, loose or damp ${ }^{(26)}$.

In relation to IMV, it is recommended to use the bundle to prevent pneumonia associated with mechanical ventilation (VAP). The measures include maintaining the bed head elevation at $30^{\circ}$ to $45^{\circ}$ degrees; monitoring of the cuff pressure of the orotracheal tube between 18 to $22 \mathrm{mmHg}$ or 25 to $30 \mathrm{cmH}_{2} \mathrm{O}$ (when using a cuff meter); oral hygiene with $0.12 \%$ chlorhexidine; daily assessment of the need to maintain sedation and extubation; 
prevention therapy for gastric ulcers and deep vein thrombosis (DVT); among others. The first measures are aimed at preventing VAP; and the last two, to prevent other complications from mechanical ventilation ${ }^{(28-30)}$.

In the prevention of urinary tract infections, the main measures are: use of aseptic technique in the insertion of the urinary bladder catheter (OBC); adequate catheter fixation, in the hypogastric region in males and in the anterolateral thigh in women; keep the urine collector below the level of the bladder and the collection bag with less than three quarters of the filled capacity, or drain the collector every eight hours or when it reaches $50 \%$ of the container; keep urinary flow unobstructed and the drainage system closed; among others ${ }^{(29-31)}$.

Numerous challenges are presented regarding the prevention and control of HAls. For example, there is a scarcity of records for evaluating the results of actions implemented in health care ${ }^{(32)}$. In addition, there are difficulties at all levels of health care: in structuring and improving material, technological and human resources for the implementation of good health care practices aimed at the prevention and control of $\mathrm{HAls}^{(32)}$.

Another important result of this study was that the length of stay in the oncology ICU of more than seven days was associated with greater chances of occurrence of sepsis or septic shock. Previous studies have found similar results ${ }^{(33-34)}$. This finding can be explained by the existence of some factors resulting from health care, namely: a) multidrug-resistant microorganisms hinder the treatment of HAls due to the lack of adequate therapy or indiscriminate use of antibiotics, which results in poor prognosis; $b$ ) the prolonged use of invasive devices; c) poor health practice - for example, failure in aseptic technique, low adherence to hand hygiene; d) clinical conditions of the cancer patient that favor the occurrence of immunosuppression and infections ${ }^{(35)}$.

In addition, the longer hospital stay is associated with malnutrition in cancer patients, and, in turn, inadequate nutrition reduces the response to treatment, affects organic functions, triggering greater complications, worse prognosis and longer hospital stay ${ }^{(3637)}$.

Also, it was identified in this study that the chance of having sepsis or septic shock with a primary hematological tumor may be greater compared to solid tumors. It is understood that patients with hematological malignancy are even more complex, as they easily get worse due to spinal immunodepression associated with chemotherapy, bone marrow transplantation, aggressive therapeutic regimens ${ }^{(37-38)}$. Thus, immunosuppression can result in increased use of antibiotics and development of infections associated with multidrug-resistant microorganisms, which makes the patient more likely to develop sepsis or septic shock ${ }^{(39)}$.

Another factor that may predispose onco-hematological patients to sepsis or septic shock are complications such as febrile neutropenia in antitumor treatment, which is more frequent in these patients, leaving them susceptible to the development of bacterial and fungal infections, which can progress to sepsis or septic shock ${ }^{(40-41)}$. Other previous studies also show that patients with hematological malignancy, when compared to solid tumors, are more vulnerable to sepsis due to the high risk of developing febrile neutropenia or HAls ${ }^{(42-43)}$.

In addition to the factors identified in this study, international investigations highlight other clinical and microbiological aspects that may increase the chance of sepsis and septic shock in cancer patients, such as chemotherapy-induced neutropenia ${ }^{(44-47)}$; the presence of biological markers - myeloid-derived granulocytic suppressor cells (G-MDSCs) after esophageal surgery ${ }^{(46)}$; solid tumors often associated with infections of the gastrointestinal $\operatorname{tract}^{(47)}$; and bacteria such as Staphylococcus spp., E. coli, K. pneumoniae, E. faecalis and S. aureus ${ }^{(48)}$.

\section{Study limitations}

This study had some limitations regarding the use of secondary data from medical records, as there were flaws in the quality of filling in information, such as inadequate filling in of laboratory results, characteristics of infectious agents (including multidrug-resistant bacteria) and location of infectious sites to relate to patients. types of invasive devices. Therefore, all of this makes it difficult to collect exposure variables for better characterization and analysis of factors associated with sepsis and septic shock.

On the other hand, data from more than $80 \%$ of patients hospitalized in the ICU in 2018 were used, which allowed to know the magnitude of sepsis and septic shock and to perform a multiple analysis of the probable characteristics related to such dysfunctions in this specific population.

Another limitation is found in the fact that the study was carried out only in a single reference center, and it is not possible to generalize the results. In addition, due to the cross-sectional design, it was not possible to establish cause and effect relationships. Also, due to the study design, it is not possible to determine the origin of the infection (whether community or hospital) that predisposed the patient to sepsis and or septic shock. Thus, cohort and multilevel studies are suggested to assess the incidence as well as the individual and environmental characteristics of the assistance provided by the health team to cancer patients.

\section{Contributions to the area of Nursing, Health or Public Policy}

The study of the prevalence of sepsis and septic shock and the factors related to these outcomes in cancer patients made it possible to know estimates of the magnitude of the problem, thus being able to assist in decision-making in view of the need to implement and improve institutional protocols for the prevention of this complication and, in turn, promote a better outcome for these patients.

In addition, the present work helps health and nursing professionals in the identification of modifiable factors related to health care that have been associated with the occurrence of sepsis in cancer patients. Thus, it helps to develop prevention protocols and infection control measures with a view to improving nursing care and the multidisciplinary team for cancer patients.

These results can also contribute to expand the knowledge of health professionals from other hospital environments, outpatient clinics, as well as those working in Primary Health Care, as it is important that they pay attention to the presence of community or hospital infection, since both can evolve for sepsis.

This study also generates local impact due to the fact that the statistical data brought indicate weaknesses in health care for 
cancer patients and may also be useful to encourage improvements in the application of HAI prevention measures aiming at the quality of health care and hospital cost reduction.

\section{CONCLUSIONS}

In this investigation, we found that more than half of cancer patients admitted to the ICU had a diagnosis of sepsis or septic shock. The factors associated with the occurrence of this outcome were: being from the Emergency Department, hospital stay longer than seven days, presence of four or more invasive procedures and presence of a primary hematological site. Thus, we observed that both individual clinical characteristics and factors related to health care can be associated with the occurrence of sepsis and septic shock in these patients.

Thus, we recommend the development and implementation of protocols for the prevention and control of infections related to health care, in addition to the implementation of national and international guidelines for the management of sepsis and septic shock in this group.

\section{REFERENCES}

1. Bray F, Ferlay J, Soerjomataram I, Siegel RL, Torre LA, Jemal A. Global Cancer Statistics 2018: GLOBOCAN Estimates of Incidence and Mortality Worldwide for 36 Cancers in 185 Countries. CA: Cancer J Clin Hoboken. 2018;68(6). https://doi.org/10.3322/caac.21492

2. Ferlay J, Ervik M, Lam F, Colombet M, Mery L, Piñeros M, et al. Global Cancer Observatory: Cancer Today. Lyon, França: Agência Internacional de Pesquisa sobre o Câncer[Internet]. 2018 [cited 2020 Nov 28]. Available from: https://gco.iarc.fr/today

3. Ministério da Saúde (BR). Estimativa 2020: incidência de câncer no Brasil[Internet]. 2019 [cited 2020 Jun 27]. Available from: https://www. inca.gov.br/sites/ufu.sti.inca.local/files/media/document/estimativa-2020-incidencia-de-cancer-no-brasil.pdf

4. Valle TD, Garcia PC. Critérios de admissão do paciente oncológico em Unidades de Terapia Intensiva de hospitais gerais. Rev Ciênc Méd. 2018;27(2). https://doi.org/10.24220/2318-0897v27n2a4121

5. Lobo SM, Rezende E, Mendes CL, Oliveira MC. Mortality due to sepsis in Brazil in a real scenario: the Brazilian ICUs project. Rev Bras Ter Intensiva. 2019;1(31). https://doi.org/10.5935/0103-507X.20190008

6. Singer MS, Deutschman CS, Seymour CW, Shankar-Hari M, Annane D, Bauer M, et al. The Third International Consensus Definitions for Sepsis and Septic Shock (Sepsis-3). JAMA. 2016;315(8):801-10. https://doi.org/10.1001/jama.2016.0287

7. Chen YJ, Chen FL, Chen JH, Wu MM, Chen YL, Chien DS, et al. Epidemiology of sepsis in Taiwan. Medicine (Baltimore). 2019;98(20). https:// doi.org/10.1097/MD.0000000000015725

8. Shelton BK, Stanik-Hutt J, Kane J, Jones RJ. Implementing the surviving sepsis campaign in an ambulatory clinic for patients with hematologic malignancies. Clin J Oncol Nurs. 2016;20(3). https://doi.org/10.1188/16.CJON.281-288

9. Tian HC, Zhou JF, Weng L, Hu XY, Peng JM, Wang CY, et al. Epidemiology of Sepsis-3 in a sub-district of Beijing. Chinese Med J. 2019;132(17). https://doi.org/10.1097/CM9.0000000000000392

10. Rudd KE, Johnson SC, Agesa KM, Shackelford KA, Tsoi D, Kievlan DR, et al. Global, regional, and national sepsis incidence and mortality, 1990-2017: analysis for the Global Burden of Disease Study. Lancet. 2020;395(10219). https://doi.org/10.1016/S0140-6736(19)32989-7

11. Levy MM, Evans LE, Rhodes AA. The Surviving Sepsis Campaign Bundle: 2018. Crit Care Med. 2018;6(44):925-928. https://doi.org/10.1097/ CCM.0000000000003119

12. Torres VBL, Azevedo LCP, Ulysses VA, Silva UVA, Caruso P, Torelly AP, et al. Sepsis-Associated outcomes in critically ill patients with malignancies. ATS J. 2015;8(12). https://doi.org/10.1513/AnnalsATS.201501-0460C

13. Martelletti BRSJ, Martillo LR, Santos LR, Santos LCG, Ferrão AARCN, Pereira JM, et al. Perfil sociodemográfico e clínico de pacientes com câncer internados em uma Unidade de Terapia Intensiva adulto. Rev Eletrôn Acervo Saúde. 2019;11(13). https://doi.org/10.25248/reas. e985.2019

14. Kameo SY, Souza DF, Nogueira JF, Santos LC, Amorim BF. Oncology emergencies: integrative literature review. Rev Bras Cancerol. 2018;4(64). https://doi.org/10.32635/2176-9745.RBC.2018v64n4.203

15. Ministério da Saúde (BR). Conselho nacional de saúde. Resolução n. 466, de 12 de dezembro de 2012: Diretrizes e normas regulamentadoras de pesquisa envolvendo seres humanos [Internet]. 2012 [cited 2020 Jun 27]. Available from: https://conselho.saude.gov.br/ resolucoes/2012/Reso466.pdf

16. Conselho Federal de Enfermagem (Cofen). Resolução n. 564, de dezembro de 2017. Aprova o novo código de ética dos profissionais de enfermagem [Internet]. Brasília. 2017 [cited 2020 Jun 27]. Available from: http://www.cofen.gov.br/wpcontent/uploads/2017/12/ RESOLU\%C3\%87\%C3\%830-COFEN-N\%C2\%BA-564-2017.pdf

17. Zonta PFNS, Velasquez PGA, Velasquez LG, Demetrio LS, Miranda D, Silva MCBD. Características epidemiológicas e clínicas da sepse em um hospital público do Paraná. Rev Epidemiol Control Infec. 2018;8(3). https://doi.org/10.17058/reci.v8i3.11438

18. Danahy DB, Jensen IJ, Griffith TS, Badovinac VP. Cutting edge: polymicrobial sepsis has the capacity to reinvigorate tumor-infiltrating CD8 T cells and prolong host survival. J Immunol. 2019;202(10). https://doi.org/10.4049/jimmunol.1900076

19. Baylot C, Francopoulo A, Gross-Goupil M, Quivy A, Guisset O, Hilbert G, et al. Prognostic factors for cancer patient admitted to a medical 
intensive care unit. Acta Oncol. 2020;59(4). https://doi.org/10.1080/0284186X.2019.1711171

20. Andrade DC, Sousa, EV, Simões KM, Holanda AR, Siza MAF, Oliveira PCA, et al. Prevalência de sepse na unidade de tratamento intensivo e os fatores associados. Braz J Surg Clin Res[Internet]. 2018 [cited 2020 Sep 30];22(3). Available from: https://www.mastereditora.com.br/ periodico/20180504_105654.pdf

21. Reilly JP, Anderson BJ, Hudock KM, Dunn TG, Kazi A, Tommasini A, et al. Neutropenic sepsis is associated with distinct clinical and biological characteristics: a cohort study of severe sepsis. Critical Care. 2016;222(20). https://doi.org/10.1186/s13054-016-1398-y

22. Luz Filho CA, Marinho CMM, Santos MDP. Fatores de risco em pacientes com sepse em unidades de terapia intensiva: uma revisão integrativa. Rev Eletrôn Acervo Saúde. 2018. https://doi.org/10.25248/reas.e208.2019

23. Wang YG, Zhou JC, Wu KS. High 28-day mortality in critically ill patients with sepsis and concomitant active cancer. J Int Med Res. 2018; 46(12). https://doi.org/10.1177/0300060518789040

24. Palmer K, Wang E, Mohanty M. Improving door to needle time in neutropenic sepsis. Future Healthc J. 2020;7(Suppl 1):s63. https://doi. org/10.7861/clinmedicine.15-6-526

25. Cunha DAO, Cunha RL, Santos MLSC, Oliveira EM, Soares RS, Fuly PSC. Profile of patients admit ted in a oncological intensive therapy unit. Cienc Cuid Saude. 2018;17(2). https://doi.org/10.4025/cienccuidsaude.v17i2.40365

26. Silva AL, Dutra S. Estratégias e metodologias educativas utilizadas na prevenção de infecções nos hospitais universitários públicos do brasil. J Infect Control [Internet]. 2019 [cited 2020 Sep 30];8(4). Available from: https://jic-abih.com.br/index.php/jic/article/view/277/pdf

27. Moore JX, Akinyemiju T, Bartolucci A, Wang HE, Waterbor J, Griffin R. A prospective study of cancer survivors and risk of sepsis within the REGARDS cohort. Cancer Epidemiol. 2018;55. https://doi.org/10.1016/j.canep.2018.05.001

28. Yoshida T, Silva AEBC, Simões LLP, Guimarães RA. Incidence of central venous catheter-related bloodstream infections: evaluation of bundle prevention in two intensive care units in Central Brazil. Scient World J. 2019;ID1025032. https://doi.org/10.1155/2019/1025032

29. Ediboğlu Ö, Kirakli Sc, Yazicioğlu Moçin Ö, Güngör G, Anar C, Çimen P, et al. Predictors of mortality in cancer patients who need intensive care unit support: a two center cohort study. Turk J Med Sci. 2018;48. https://doi.org/10.3906/sag-1710-158

30. Ferreira LL, Azevedo LMN, Salvador PTCO, Morais SHM, Paiva RM, Santos VEP. Nursing care in healthcare-associated infections: a scoping review. Rev Bras Enferm. 2019;72(2). https://doi.org/10.1590/0034-7167-2018-0418

31. World Health Organization (WHO). Minimum requirements for infection prevention and control programmes [Internet]. 2019 [cited 2021 Apr 19]. Available from: https://apps.who.int/iris/bitstream/handle/10665/330080/9789241516945-eng.pdf?ua=1

32. Ministério da saúde (BR). Programa nacional de prevenção e controle de infecções relacionadas à assistência à saúde (PNPCIRAS) 2021 a 2025 [Internet]. 2021 [cited 2021 Apr 18]. Available from: https://www.gov.br/anvisa/pt-br/centraisdeconteudo/publicacoes/ servicosdesaude/publicacoes/pnpciras_2021_2025.pdf

33. Mota EC, Oliveira AC. Prevention of catheter-associated urinary tract infection: what is the gap in clinical practice?. Texto Contexto Enfermagem. 2019;28. https://doi.org/10.1590/1980-265X-TCE-2018-0050

34. Baykara N, Akalın H, Arslantaş MK, Hancı V, Çağlayan Ç, Kahveci F, et al. Sepsis Study Group. Epidemiology of sepsis in intensive care units in Turkey: a multicenter, point-prevalence study. Crit Care. 2018.22:id93. https://doi.org/10. 1186/s13054-018-2013-1

35. Hensley MK, Donnelly JP, Carlton EF, Prescott HC. Epidemiology and outcomes of cancer-related versus non-cancer-related sepsis hospitalizations. Crit Care Med. 2019;47(10):1310-6. https://doi.org/10.1097/CCM.0000000000003896

36. Coopersmith CM, Backer D, Deutschman CS, Ferrer R, Lat I, Machado FR, et al. Surviving sepsis campaign: research priorities for sepsis and septic shock. Intensive Care Med. 2018;4(9). https://doi.org/10.1007/s00134-018-5175-z

37. Villardo GP, Segadilha NLAL, Rocha EEM. Protein adequacy versus nutritional status of adult oncology patients in intensive care unit. Rev Bras Cancerol. 2018;64(4):527-32. https://doi.org/10.32635/2176-9745.RBC.2018v64n4.201

38. Kempker JA, Martin GS. A global accounting of sepsis. Lancet. 2020;395(10219):168-70. https://doi.org/10.1016/S0140-6736(19)33065-X

39. Braga CC, Taplitz RA, Flowers CR. Clinical Implications of Febrile Neutropenia Guidelines in the Cancer Patient Population. J Oncol Pract. 2019;15(1). https://doi.org/10.1200/JOP.18.00718

40. Rhee C, Wang R, Zhang Z, Fram D, Kadri SS, Klompas M. Prevention epicenters program. epidemiology of hospital-onset versus communityonset sepsis in U.S. hospitals and association with mortality: a retrospective analysis using electronic clinical data. Crit Care Med. 2019;47(9). https://doi.org/10.1097/CCM.0000000000003817

41. Cruz GC, Maldonado JV, Frías-Toral E, García CZ. Mortalidad de Pacientes Oncológicos vinculados a Neutropenia. Rev Oncol ECU. 2019;29(1):12-6. https://doi.org/10.33821/279

42. Bou Chebl R, Safa R, Sabra M, Chami A, Berbari I, Jamali S, et al. Sepsis in patients with haematological versus solid cancer: a retrospective cohort study. BMJ Open. 202;11(2). https://doi.org/10.1136/bmjopen-2020-038349

43. Al-Zubaidi N, Shehada E, Alshabani K, ZazaDitYafawi J, Kingah P, Soubani AO. Predictors of outcome in patients with hematologic malignancies admitted to the intensive care unit. Hematol Oncol Stem Cell Ther. 2018;11(4). https://doi.org/10.1016/j.hemonc.2018.03.003

44. Kochanek M, Schalk E, von Bergwelt-Baildon M, Beutel G, Buchheidt D, Hentrich M, et al. Management of sepsis in neutropenic cancer patients: 2018 guidelines from the Infectious Diseases Working Party (AGIHO) and Intensive Care Working Party (iCHOP) of the German Society of Hematology and Medical Oncology (DGHO). Ann Hematol. 2019;98:1051-69. https://doi.org/10.1007/s00277-019-03622-0 
45. Aballea MLC, Caballero IA. Sepsis en pacientes con tumores sólidos en quimioterapia. Cienc Salud. 2020;4(3). https://doi.org/10.22206/ cysa.2020.v4i3.pp53-61

46. Xu J, Peng Y, Yang M, Guo N, Liu H, Gao H, et al. Increased levels of myeloid-derived suppressor cells in esophageal cancer patients is associated with the complication of sepsis. Biomed Pharmacother. 2020;125. https://doi.org/10.1016/j.biopha.2020.109864

47. Tripath H, Mukhopadhyay S, Mohapatra SK. Sepsis-associated pathways segregate cancer groups. BMC Cancer 2020;20:309. https://doi. org/10.1186/s12885-020-06774-9

48. Chinowaita F, Chaka W, Nyazika TK, Maboreke TC, Tizauone E, Mapondera P, et al. Sepsis in cancer patients residing in Zimbabwe: spectrum of bacterial and fungal aetiologies and their antimicrobial susceptibility patterns. BMC Infect Dis. 2020;20(1). https://doi.org/10.1186/ s12879-020-4886-2 